\title{
The outcrop of the Menilite Beds in Kobielnik village - its geoeductional significance and an example of determining structural position based on clastic dykes
}

\author{
Maria Barmuta, Jan Barmuta, Jan Golonka \\ AGH University of Science and Technology, Faculty of Geology, Geophysics and Environmental Protection, \\ al. Mickiewicza 30, 30-059 Kraków; \\ e-mail:mariabarmuta@gmail.com, jbarmuta@geol.agh.edu.pl,jgolonka@agh.edu.pl
}
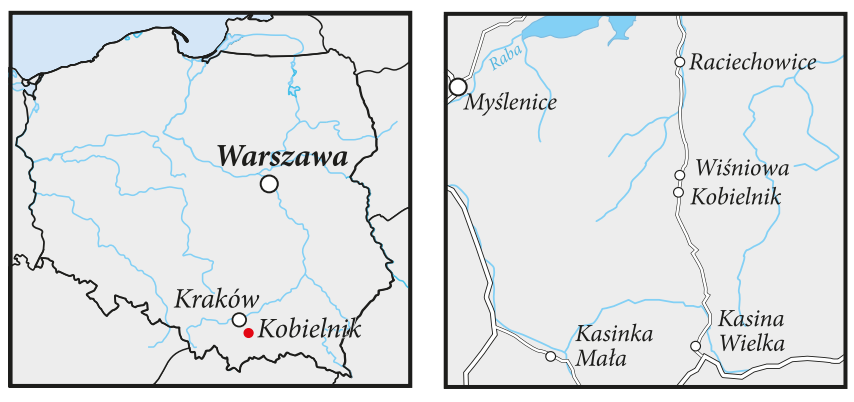

\begin{abstract}
The location and most interesting geological features of the outcrop of the Menilite Beds in Kobielnik village were described in the text. However, the main subject is the problem of determining the structural position in the absence of typical indicators of the bed's top and bottom. The proposed solution is based on the observation of clastic dykes and their structural relationship to the surrounding layers. In addition, some sedimentary structures and natural bitumen's seepages were described.
\end{abstract}

Key words: Menilite Beds, clastic dykes, geotourism

\section{Introduction}

The annual program of field training for students of the Faculty of Geology and Geotourism includes visits to selected geological outcrops with the assistance of the Faculty lecturers'. One of these exposures is the Menilite Beds in Kobielnik. Among other subjects, this particular exposure is usually used to demonstrate and discuss the phenomenon of the overturned position of the beds. However, the typical indicators of top and bottom of the bed, like hieroglyphs or Bouma sequence elements, are not present or developed in the Menilite Beds as in the case of other divisions of the Flysch Carpathians. A general knowledge of the Menilite Beds profile provides evidence that the beds in Kobielnik are overturned, but having this knowledge should not be immediately expected from the first year students. The authors propose an alternative method to explicitly demonstrate the overturned position of the beds. It is shown further in this paper that the particular features of clastic dykes observed in the exposure indirectly determine the situation of the beds.

\section{Geographical location, description of the exposure and brief characteristics of Menilite Beds}

Kobielnik village is in the South-Eastern part of the Makowski Beskid known also as the Middle Beskid. The subject exposure can be found in the right bank of the Kobielnik creek cutting into the West slope of Świnia Góra. The exposure can be reached by walking from the PKS Kobielnik Pocekaj bus stop and across the bridge over the creek. Just behind the bridge one should turn right onto the dust path that leads directly to the outcrop (around $70 \mathrm{~m}$ ).

Geologically, Menilite Beds are one of lito-stratigraphic divisions within the Śląska nappe (Fig. 1, Fig. 2), and were deposited in the Krosno basin (Golonka, Waśkowska-Oliwa, 2007).

The age of Menilite Beds is determined as Oligocene, yet it is worth noting that, in other units of Flysch Carpathians the sedimentation in the Krosno basin could continue until the Early Miocene.

In the stratigraphic profile, the Globigerina Marls can be found below the Menilite Beds, while above them - thick Krosno Beds. The research indicates that depositional environment was most likely an outer shelf and the depth was varying between normal and storm wave base (Dziadzio et al., 2006; Olszewska 1984). The characteristic feature of the beds is the high content of organic matter. Because of this they are seen as one of the most significant source rocks in the Outer Carpathians (Dziadzio et al., 2006; Krobicki et al., 2012).

\section{Description of the exposure}

The profile of the Menilite Beds can be investigated in a relatively large outcrop (around $30 \mathrm{~m}$ ) (Fig. 3). The beds are steep (deep $50^{\circ}$, dip direction $218^{\circ}$ ) and mainly mudstones showing shale type cleavage. Several layers of polimictic conglomerates, with grain size varying from several millimeters to several centimeters, are also observed in the profile. The conglomerates often contain exotic elements, mainly fragments of coal up to $10-15$ centimeters in size (Fig. 4A). In the shale layers, seepages of bitumens can be found (Fig. 4B). 


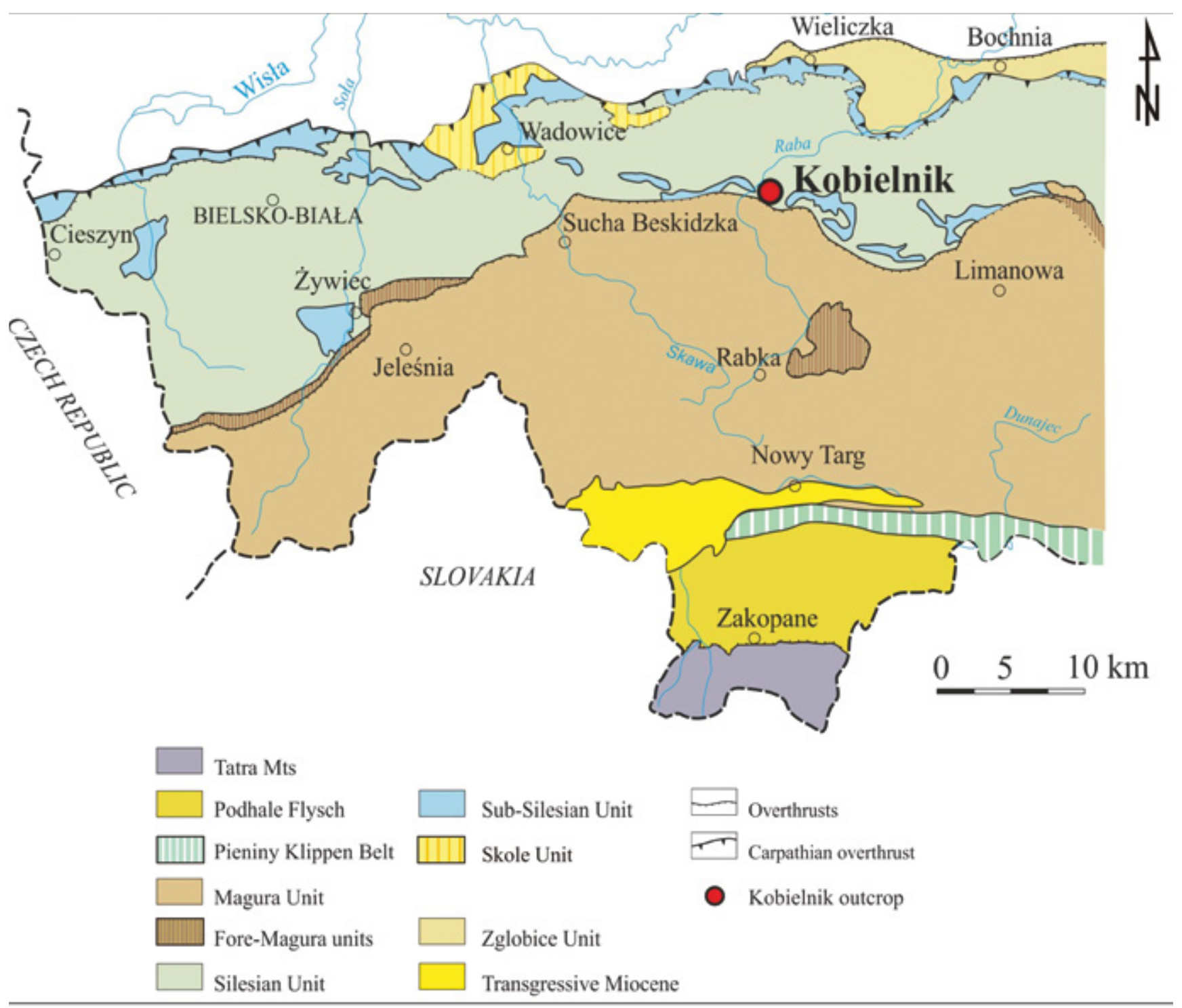

Fig. 1. Geologic map of the western part of the Polish Outer Carpathians with location of the Kobielnik outcrop (after Lexa et al., 2000)

The presence of bitumens and abundance of fish fossils within the shale beds make the exposure particularly suitable for explaining and presenting the genesis of hydrocarbons and elements of oil and gas geology, e.g. source rock and reservoir rock. Going further up along the creek, thin layers of cherts and beds of sandstone up to 50 $\mathrm{cm}$ thick can be found in the outcrop. The cherts are brownish black resulting from the content of a dark brown form of opal (menilite). The small waterfall, that can be seen nearby in the creek is apparently formed by highly resistant siliceous marls. Apart from the mentioned exotic fragments, seepages of bitumen and fish fossils many, interesting sedimentary structures can be found in the exposure. There are several clearly defined load casts on one of the conglomerate beds (Fig. 4c). The fact that they are seen on the upward facing plane also indicates an overturned position of the beds. In addition, one of the conglomerate beds shows reversely graded grains. Another point of interest is a small concentration of calcite crystals found on the conglomerate layer. Yet, the paramount feature of the exposure is the presence of numerous clastic dykes. The largest one is located on its right side (Fig. 3, Fig. 5). The dyke consists of material entirely different from material that can be found in conglomerate or shale beds. It is characterized by relatively good sorting (equigranular), iron staining on the weathered surface, psammitic fraction and less variable composition compared to conglomerates. The rock of the dyke is also very brittle. About $10 \mathrm{~m}$ further up the creek, along its right bank, there are more clastic dykes that form tail-like shapes along the slope. Several sandstone beds are also exposed there. Considering the macroscopic similarity of the material found in sandstones and dykes, it was determined that the sandstone beds were the source material for the dykes. Another interesting structure observed between two clastic dykes is a small fold of around $50 \mathrm{~cm}$ amplitude (Fig. 6). Its shape resembles a chevron fold, yet most likely it is of post-sedimentary origin. The genesis of this fold will be explained further in this paper. 


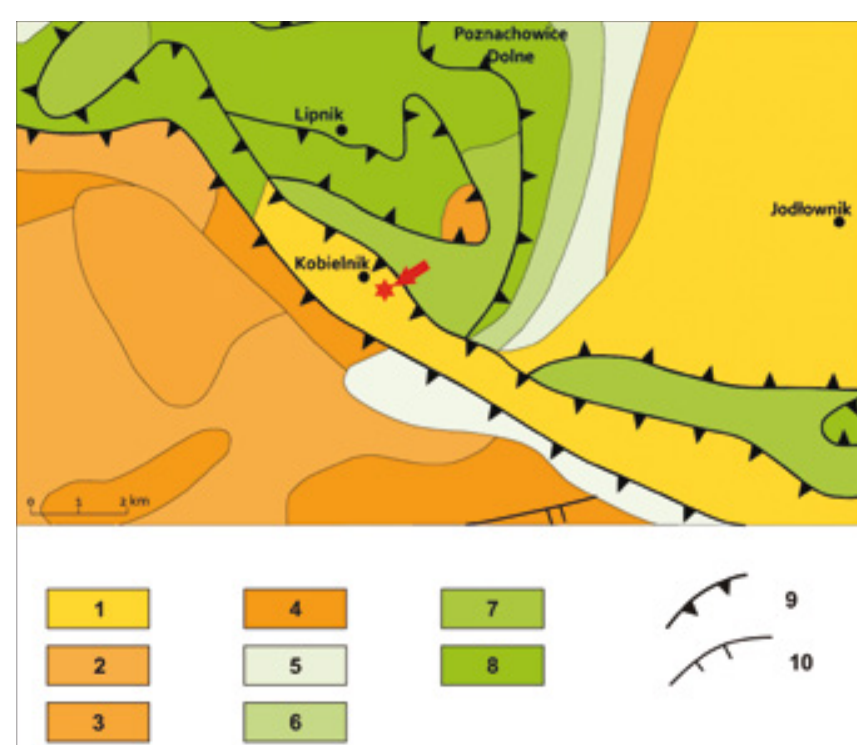

Fig. 2. Geologic sketch of the Kobielnik outcrop (after Lexa et al., 2000). Red arrow indicates the outcrop location. Explanations: 1 Menilite and Krosno formations, 2 - Pasierbiec and Osielec Sandstones; 3 - Hieroglyphic Formation; 4 - Beloveza Beds; 5-6 - Istebna Formation; 7-8 - Cieszyn-Hradište formations; 9 - first order overthrust lines; 10 - second order overthrust lines.

Szkic geologiczny odsłonięcia w Kobielniku (na podstawie Lexa et al., 2000). Czerwoną strzałką wskazano położenie odsłonięcia. Objaśnienia: 1 - warstwy menilitowe i warstwy krośnieńskie, 2 - piaskowce pasierbieckie i piaskowce osieleckie, 3 - warstwu hieroglifowe, 4-warstwy belowezkie, 5-6 - warstwy istebnieńskie, 7-8 - warstwy cieszyńskie i warstwy grodziskie, 9 - główne nasunięcia, 10 - podrzędne nasunięcia.

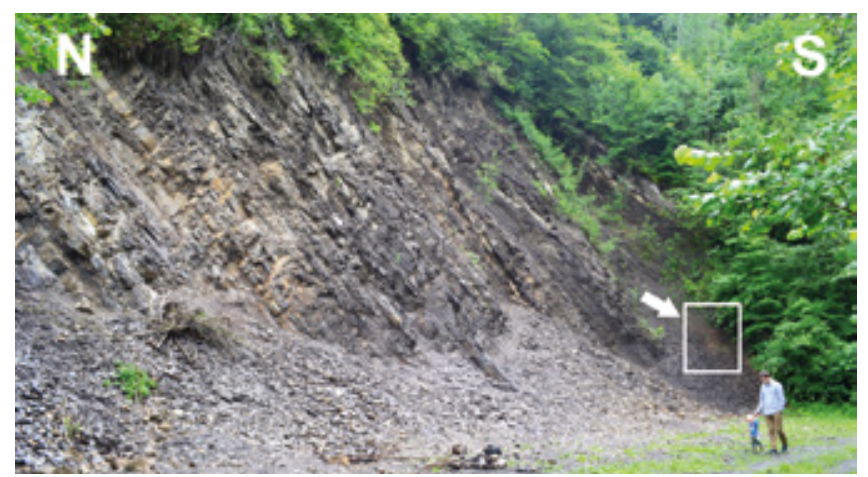

Fig. 3. Outcrop in the Kobielnik village. The location of the biggest clastic dyke (shown later on Fig. 5) is marked by white rectangle (photo M. Barmuta)

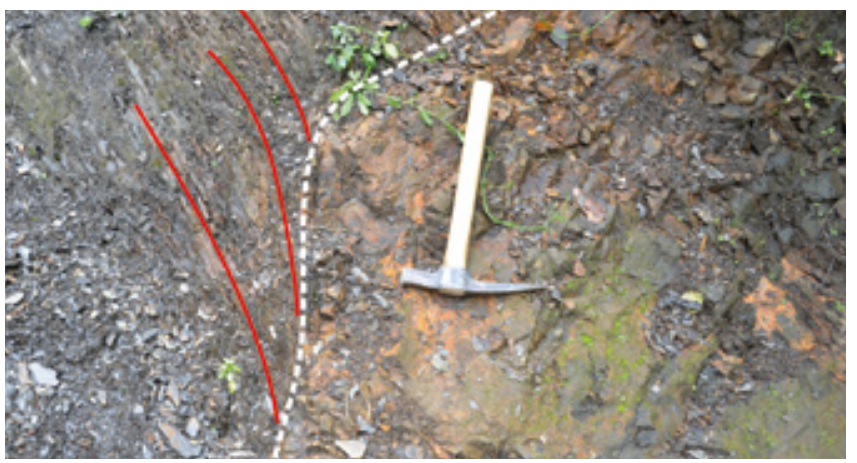

Fig. 5. Contact zone between clastic dyke and shale layers. Bending on the shale layers is underline by red lines (photo J. Barmuta)
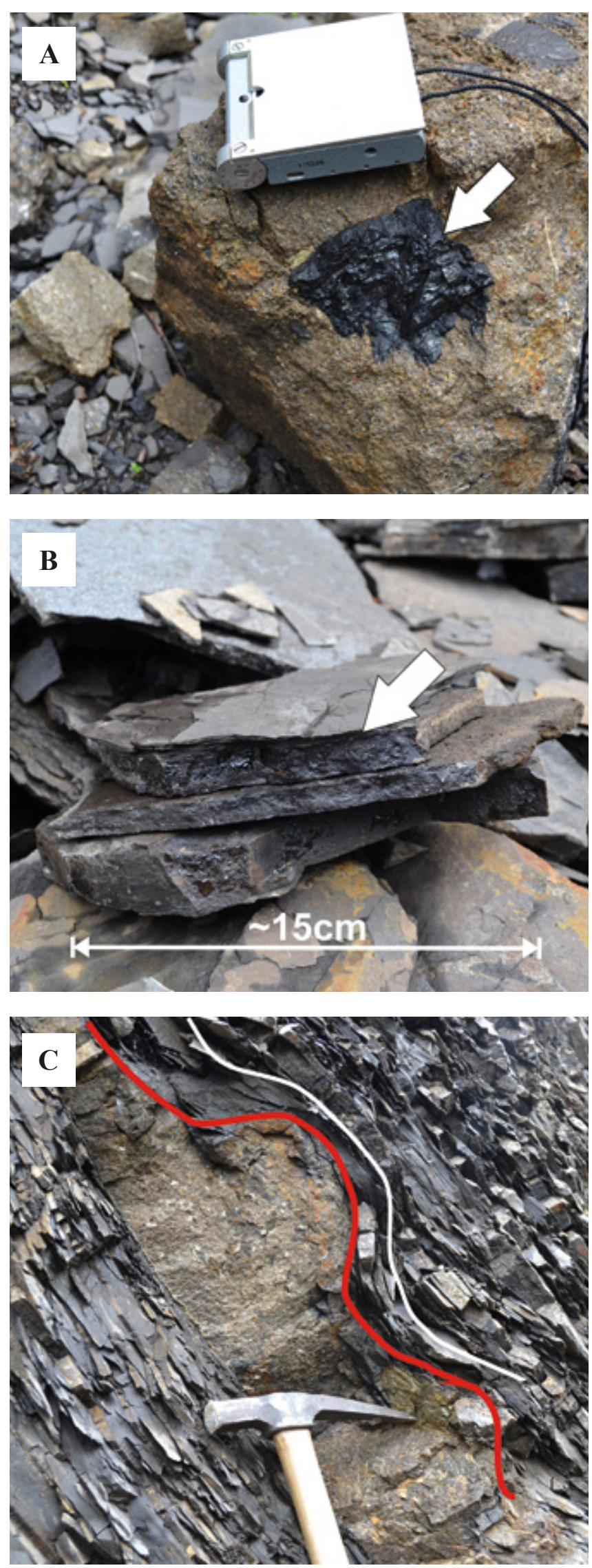

Fig. 4. Some geological phenomenon observed within Menilite Formation; A - large fragment of coal $(\sim 10 \mathrm{~cm})$, B - bitumen seepage from fragment of shale layer, $\mathrm{C}$ - load casts found in the conglomerate (photo J. Barmuta) 


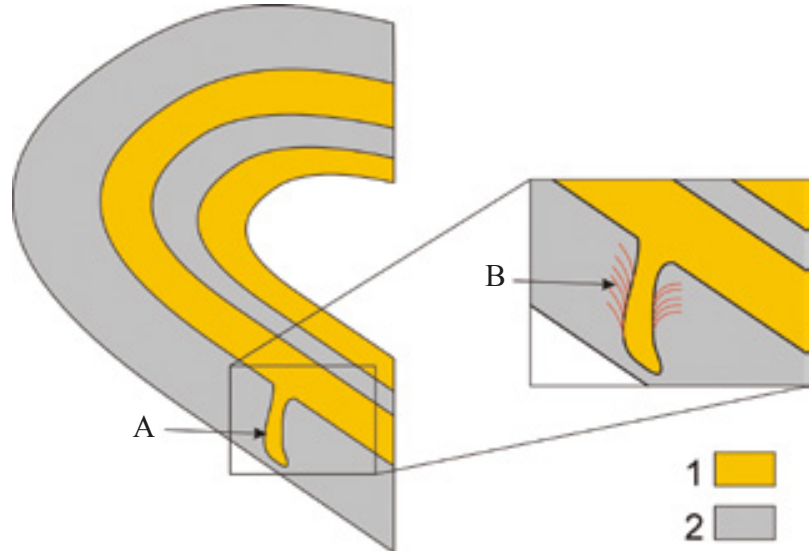

Fig. 6. Schematic sketch of clastic dyke position in the Kobielnik outcrop. 1 - shale layers, 2 - sandstone layers, A - clastic dyke, $\mathrm{B}$ - shale layers' bending around clastic dyke (own compilation)

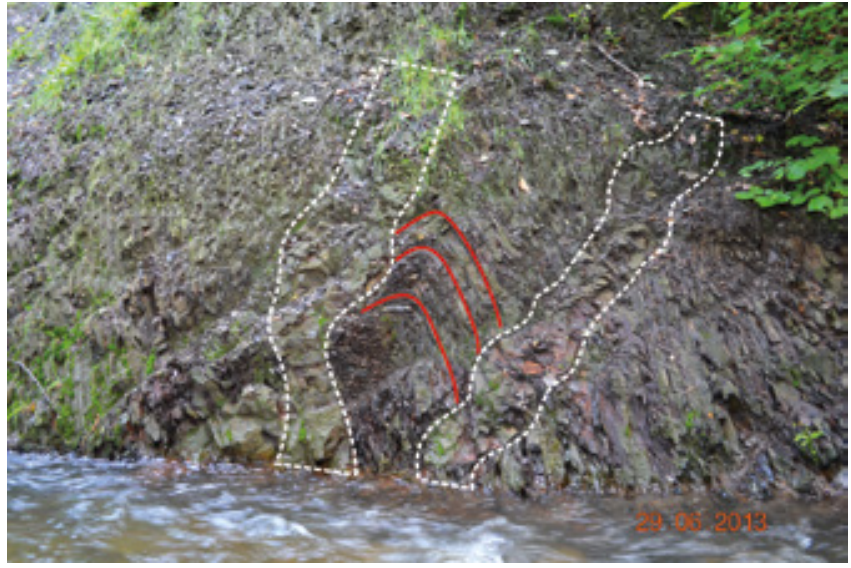

Fig. 7. Small fold $(\sim 50 \mathrm{~cm}$ height $)$ located between two clastic dykes (photo M. Barmuta)

\section{Structural position of the clastic dykes in relation to surrounding beds}

Generally, clastic dykes are defined as sedimentary structures in form of the veins oriented discordantly to bedding and intersecting the beds. The formation of dykes is explained by high water pore pressure in loose sediment under a lithified overburden. When pressure exceeds the critical fracturing pressure, the saturated material breaks through the overlying beds usually following the local weakest zones and paths (e.g. faults). By filling up the fractures it forms the characteristic clastic dykes. The direct impulses for the formation of dykes (abrupt increase of water pressure) can also be earthquakes and other violent events. The size of these structures varies within a range of meters to tenths of kilometers. Occasionally, regional size intrusions of sandy material, in the form of sill, may later become a reservoir for hydrocarbons (e.g. Balder oil field, Norway) (Imbert, 2011). Obviously, the material fracturing and intruding into the overlying beds causes the beds in the nearest vicinity of the dyke to bend in the direction of the intrusion; usually upward. However, when examining this zone of shale beds between two clastic dykes it appears the beds are bent downward (Fig. 5). Based on this observation, it becomes evident then that the whole packet of Menilite Beds was overturned after upward deformation of shale beds (Fig. 6). The earlier described folding took place during the shale beds fracturing and the dyke material moving upward. As located between two closely spaced dykes it became a syncline. What we observe now is an anticline because the beds were subsequently overturned. The non-tectonic origin of the fold is also implied by the curvature of the bend diminishing together with the direction of the intruding material (Fig. 7).

\section{Conclusions}

The exposure in Kobielnik is certainly a very attractive and useful for the purpose of promoting teaching of geological science. It allows for a demonstration and a discussion of many topics from various fields of geology of which only few have been described in this paper. The authors presented the exposure to a group of a dozen or so visitors generally unfamiliar with geological science. The observation proves that this particular location invokes high interest especially in the origin and migration of hydrocarbons, fossilized fragments of fish and the mechanisms for the formation of clastic dykes.

The authors suggest the reasoning based on the genesis of clastic dykes and their effect on the surrounding layers, that leads to the conclusion of the overturn of beds, can be an additional and interesting example of geological analysis to be presented on site to geology students and a general audience.

\section{References}

Dziadzio P., Borys Z., Kuk S., Masłowski E., Probulski J., Pietrusiak M., Górka A., Moryc J., Baszkiewicz A., Karnkowski P., Karnkowski P.H., Pietrusiak M., 2006. Hydrocarbon resources of the Polish Outer Carpathians - Reservoir parameters, trap types, and selected hydrocarbon fields: A stratigraphic review. In: Golonka J., Picha F.J., The Carpathians and their foreland: Geology and hydrocarbon resources: AAPG Memoir 84: 259-291.

Golonka J., Waśkowska-Oliwa A, 2007, Stratygrafia polskich Karpat fliszowych pomiędzy Bielskiem-Białą a Nowym Targiem. Geologia (kwartalnik AGH), 33, 4/1: 5-28.

Imbert P., 2011, Industrial Application of Deep-Sea Sediments. In: Hüneke H., Mulder T. (eds), Deep-sea sediments. Developments in Sedimentology. Elsevier, Amsterdam, 63: 715-764.
Krobicki M., Golonka J., Ślączka A., 2012. The Carpathians - Menilite Shale as the main oil source in the Carpathians: field trip, leaders: Michał Krobicki, Jan Golonka, with Contribution of Andrzej Ślączka. In: GeoShale 2012: recent advances in geology of fine-grained sediments: international conference: 14-16 May 2012, Polish Geological Institute - National Research Institute, Warsaw: 195-233.

Lexa J., Bezák V., Elečko M., Mello J., Polák M., Potfaj M., Vozár J. (eds) 2000. Geological map of Western Carpathians and adjacentareas 1:500 000. Geological Survey of Slovak Republic, Bratislava.

Olszewska B., 1984. Interpretacja paleoekologiczna otwornic kredy i paleogenu polskich Karpat Zewnętrznych, Biuletyn Instytutu Geologicznego, 346: 7-53. 